\title{
In Situ Raman Spectroscopy of Supported Chromium Oxide Catalysts: Reactivity Studies with Methanol and Butane
}

\author{
Bert M. Weckhuysen ${ }^{* \dagger \dagger}$ and Israel E. Wachs \\ Zettlemoyer Center for Surface Studies, Department of Chemical Engineering, Lehigh University, \\ 7 Asa Drive, Bethlehem, Pennsylvania 18015
}

Received: February 22, $1996^{\otimes}$

\begin{abstract}
The interactions of methanol and butane with supported chromium oxide catalysts under oxidizing and reducing conditions were studied by in situ Raman spectroscopy as a function of the specific oxide support $\left(\mathrm{Al}_{2} \mathrm{O}_{3}\right.$, $\mathrm{ZrO}_{2}, \mathrm{TiO}_{2}, \mathrm{SiO}_{2}, \mathrm{Nb}_{2} \mathrm{O}_{5}, 3 \% \mathrm{SiO}_{2} / \mathrm{TiO}_{2}, 3 \% \mathrm{TiO}_{2} / \mathrm{SiO}_{2}$, and a physical mixture of $\mathrm{SiO}_{2}$ and $\left.\mathrm{TiO}_{2}\right)$ and chromium oxide loading $\left(1-6 \mathrm{wt} \% \mathrm{CrO}_{3}\right)$. Two surface chromium oxide species were observed on the $\mathrm{TiO}_{2}$, $\mathrm{ZrO}_{2}, \mathrm{Al}_{2} \mathrm{O}_{3}, 3 \% \mathrm{SiO}_{2} / \mathrm{TiO}_{2}$, and a physical mixture of $\mathrm{SiO}_{2}$ and $\mathrm{TiO}_{2}$ surfaces: a monomeric species (characterized by a $\mathrm{Cr}=\mathrm{O}$ stretching frequency at $\sim 1030 \mathrm{~cm}^{-1}$ ) and a polymeric species (possessing a $\mathrm{Cr}=\mathrm{O}$ stretching frequency at $\sim 1005-1010 \mathrm{~cm}^{-1}$ and a $\mathrm{Cr}-\mathrm{O}-\mathrm{Cr}$ bending mode at $\sim 880 \mathrm{~cm}^{-1}$ ). $\mathrm{The}^{\mathrm{SiO}} \mathrm{O}_{2}$ and $3 \% \mathrm{TiO}_{2} / \mathrm{SiO}_{2}$ surfaces possess only the monomeric species. The extent of reduction of the surface chromium oxide species, reflected by the decrease in the Raman intensity of the $\mathrm{Cr}=\mathrm{O}$ bonds, demonstrates that the polymeric surface chromium oxide species is more easily reducible than the monomeric chromium oxide species on the same support. The extent of reduction of the surface chromium oxide species strongly depends on the specific oxide support $\left(3 \% \mathrm{TiO}_{2} / \mathrm{SiO}_{2} \approx 3 \% \mathrm{SiO}_{2} / \mathrm{TiO}_{2} \approx\left(\mathrm{SiO}_{2}+\mathrm{TiO}_{2}\right) \approx \mathrm{TiO}_{2}>\mathrm{ZrO}_{2}\right)$.
\end{abstract}

\section{Introduction}

Supported chromium oxide catalysts are crucial in the chemical industry for the production of several important commodity chemicals. ${ }^{1-9} \mathrm{Cr} / \mathrm{SiO}_{2}$ catalysts are known as the Phillips catalyst for the production of high-density polyethylene (HDPE) and linear low density polyethylene (LLDPE), and $\mathrm{Cr} / \mathrm{Al}_{2} \mathrm{O}_{3}$ catalysts are used for the dehydrogenation of butane to butene. The industrial importance of chromium oxide catalysts has attracted a great deal of interest in industrial and academic research toward the elucidation of the molecular structure of supported chromium oxides. This subject has been recently reviewed by us and there is now a general consensus that different oxidation and coordination states of $\mathrm{Cr}$ $\left(\mathrm{Cr}^{n+}\right.$ with $n=2,3,5$, and 6) can be present, which depend on the pretreatment, the $\mathrm{Cr}$ loading, and the support type and composition. ${ }^{10}$

Raman spectroscopy (RS) is an excellent technique for studying supported metal oxide catalysts because this technique can discriminate between the different molecular states of supported metal oxide species since each state possess a unique vibrational spectrum that is related to its structure. ${ }^{10}$ In previous RS studies, chromium oxide catalysts were studied under hydrated and dehydrated conditions as a function of the support type and composition. ${ }^{11-21}$ These characterization studies revealed that under hydrated conditions the molecular structure of the surface chromium oxide species is only determined by the isoelectric point (IEP) or net $\mathrm{pH}$ at point of zero charge (PZC) of the support. ${ }^{20}$ The chromate:polychromate ratio increases with the IEP of the support and with decreasing $\mathrm{Cr}$ oxide loading. Upon calcination, dehydrated surface chromium oxide molecular structures are formed by reaction with the surface hydroxyl groups of the support. ${ }^{22-24}$ These dehydrated surface chromium oxide species are highly distorted and possess different structures than found in the hydrated states.

\footnotetext{
* To whom correspondence should be addressed.

$\dagger$ Present address: Centrum voor Oppervlaktechemie en Katalyse, K.U. Leuven, Kardinaal Mercierlaan 92, 3001 Heverlee, Belgium

${ }^{\otimes}$ Abstract published in Advance ACS Abstracts, August 1, 1996.
}

However, all previous characterization studies were conducted under hydrated or dehydrated conditions and, to our knowledge, no in situ Raman spectroscopy studies of supported chromium oxide catalysts under catalytic reaction conditions have appeared in the literature to date. In general, in situ Raman data under reaction conditions are presently very rare in the literature for supported metal oxide catalysts. ${ }^{25}$ A possible reason is the problem of fluorescence, which sometimes complicates the collection of Raman spectra. This is due to the presence of organic deposits formed during catalytic reactions or to the formation of reduced $\mathrm{Cr}$ species, especially $\mathrm{Cr}^{3+}$, because $\mathrm{Cr}^{3+}$ in alumina is known as a ruby laser. ${ }^{26}$

The objectives of this work are two-fold: (1) to study the feasibility of in situ Raman spectroscopy for studying supported chromium oxide catalysts under catalytic conditions and (2) to probe the reactivity of supported chromium oxide catalysts during methanol oxidation and butane dehydrogenation/oxidation. This new in situ Raman spectroscopy information allows us to provide a more complete picture of the surface chemistry of chromium oxide species on inorganic oxides.

\section{Experimental Section}

1. Catalyst Preparation and Characteristics. A series of supported chromium oxide catalysts were prepared by the incipient-wetness impregnation method with an aqueous solution of chromium nitrate, $\left(\mathrm{Cr}\left(\mathrm{NO}_{3}\right)_{3} \cdot 9 \mathrm{H}_{2} \mathrm{O}\right.$, Allied Chemical Co.). The supports used in this study were $\mathrm{Al}_{2} \mathrm{O}_{3}, \mathrm{ZrO}_{2}, \mathrm{Nb}_{2} \mathrm{O}_{5}, \mathrm{SiO}_{2}$, $\mathrm{TiO}_{2}, 3 \% \mathrm{SiO}_{2} / \mathrm{TiO}_{2}, 3 \% \mathrm{TiO}_{2} / \mathrm{SiO}_{2}$, and a physical mixture of $\mathrm{SiO}_{2}$ and $\mathrm{TiO}_{2}$. Details about the preparation method of the $3 \% \mathrm{SiO}_{2} / \mathrm{TiO}_{2}, 3 \% \mathrm{TiO}_{2} / \mathrm{SiO}_{2}$, and a physical mixture of $\mathrm{SiO}_{2}$ and $\mathrm{TiO}_{2}$ supports are reported elsewhere. ${ }^{16}$ The characteristics of the supports and the studied supported chromium oxide catalysts are summarized in Table 1. After impregnation, the wet samples were initially dried at room temperature for $16 \mathrm{~h}$, further dried at $110-120{ }^{\circ} \mathrm{C}$ for $16 \mathrm{~h}$, and calcined at $500{ }^{\circ} \mathrm{C}$ for $16 \mathrm{~h}$.

2. Raman Spectroscopy. Raman spectra of the supported chromium oxide catalysts were obtained with a laser Raman 
TABLE 1: Overview of the Characteristics of the Supported Chromium Oxide Catalysts

\begin{tabular}{|c|c|c|}
\hline Cr catalysts & $\begin{array}{c}\mathrm{CrO}_{3} \text { content } \\
(\mathrm{wt} \%)\end{array}$ & support characteristics \\
\hline $\mathrm{CrO}_{3} / \mathrm{SiO}_{2}$ & 1,3 & Cab-O-Sil, $300 \mathrm{~m}^{2} / \mathrm{g}$ \\
\hline $\mathrm{CrO}_{3} / \mathrm{ZrO}_{2}$ & $1,3,6$ & Degussa, $39 \mathrm{~m}^{2} / \mathrm{g}$ \\
\hline $\mathrm{CrO}_{3} / \mathrm{Al}_{2} \mathrm{O}_{3}$ & 5 & Harshaw, $180 \mathrm{~m}^{2} / \mathrm{g}$ \\
\hline $\mathrm{CrO}_{3} / \mathrm{TiO}_{2}$ & 3 & Degussa, $55 \mathrm{~m}^{2} / \mathrm{g}$ \\
\hline $\mathrm{CrO}_{3} / 3 \% \mathrm{TiO}_{2} / \mathrm{SiO}_{2}$ & 1 & prepared from $\mathrm{SiO}_{2}(\mathrm{Cab}-\mathrm{O}-\mathrm{Sil})$ \\
\hline $\mathrm{CrO}_{3} / 3 \% \mathrm{SiO}_{2} / \mathrm{TiO}_{2}$ & 1 & prepared from $\mathrm{TiO}_{2}$ (Degussa) \\
\hline $\mathrm{CrO}_{3} /\left(\mathrm{TiO}_{2}+\mathrm{SiO}_{2}\right)$ & 1 & $\begin{array}{l}\text { physical mixture of } \mathrm{SiO}_{2} \\
\text { (Cab-O-Sil) and } \mathrm{TiO}_{2} \\
\text { (Degussa) }\end{array}$ \\
\hline $\mathrm{CrO}_{3} / \mathrm{Nb}_{2} \mathrm{O}_{5}$ & 1 & $\begin{array}{l}\text { from } \mathrm{Nb}_{2} \mathrm{O}_{5} \cdot 4 \mathrm{H}_{2} \mathrm{O} \text {, Niobium } \\
\text { Products Co., calcined at } \\
773 \mathrm{~K} \text { for } 6 \mathrm{~h}\end{array}$ \\
\hline
\end{tabular}

apparatus with the $514.5 \mathrm{~nm}$ line of an $\mathrm{Ar}^{+}$laser (Spectra Physics, Model 171) as the excitation source. The laser power at each sample was about $40 \mathrm{~mW}$. The scattered radiation from the sample was directed into a Spex Triplemate spectrometer (Model 1877) coupled to a Princeton Applied Research (Model 1463) OMA III optical multichannel photodiode array detector (1024 pixels). The detector was cooled thermoelectronically to $-35^{\circ} \mathrm{C}$ to decrease the thermal noise. The Raman scattering in the $600-1100 \mathrm{~cm}^{-1}$ region was collected, and the spectra were recorded using an OMA III computer and software. The instrument resolution was experimentally determined to be better than $2 \mathrm{~cm}^{-1}$. About $0.2 \mathrm{~g}$ of each supported chromium oxide catalyst was pressed into a thin wafer of about $1 \mathrm{~mm}$ thickness and mounted on the sample holder in the in situ Raman cell. Additional details about the design of the in situ Raman cell can be found elsewhere. The sample was typically rotated at 1000-2000 rpm to minimize sample heating by the laser beam. To minimize possible fluorescence from the support, the catalyst samples were calcined in dry air at $500{ }^{\circ} \mathrm{C}$ for $2 \mathrm{~h}$ before the Raman measurements. The in situ Raman spectra were obtained with the following procedure. The samples were placed into the cell and heated up to $500{ }^{\circ} \mathrm{C}$ for $2 \mathrm{~h}$ in a flow of pure oxygen gas (Linde Specialty Grade, $99.99 \%$ purity). The dehydrated Raman spectra were collected after cooling the sample to 200 or $350^{\circ} \mathrm{C}$ in a flow of pure oxygen gas for $30 \mathrm{~min}$. After this treatment, butane (Air Products and Chemicals, mixture of $98.7 \% \mathrm{He}$ and $1.3 \%$ butane) or methanol vapor was introduced at temperatures between 200 and $450{ }^{\circ} \mathrm{C}$ into the cell, and the Raman spectra under reaction conditions were collected after reaching steady state (about $30 \mathrm{~min}$ ). The methanol vapor was introduced as a mixture of He (JWS Technologies, Inc., 99.99\% purity) and $\mathrm{O}_{2}$ (Linde Specialty Grade, $99.99 \%$ purity) after bubbling through a water flask of methanol in an ice bath $(\sim 4$ mol $\left.\% \mathrm{CH}_{3} \mathrm{OH}\right)$. After these treatments, the samples were recalcined at $500{ }^{\circ} \mathrm{C}$ in flowing pure oxygen gas for $30 \mathrm{~min}$. The Raman spectra were deconvoluted with a commercial software package Grams/386 of Galactics Industries Corp., and the individual Raman bands were integrated after baseline correction.

\section{Results}

1. $\mathrm{Cr} / \mathrm{SiO}_{2}$ Catalysts. The dehydrated silica-supported chromium oxide catalysts possess a Raman band at around 986 $\mathrm{cm}^{-1}$ which is characteristic of a dehydrated chromium oxide species. Previous Raman studies concluded that this chromium oxide species is predominantly present as a monochromate species. ${ }^{12,13}$ A fluorescence background, however, is induced under butane dehydrogenation/oxidation and methanol oxidation, which overshadows the Raman features of the surface chromium oxide species under reaction conditions.

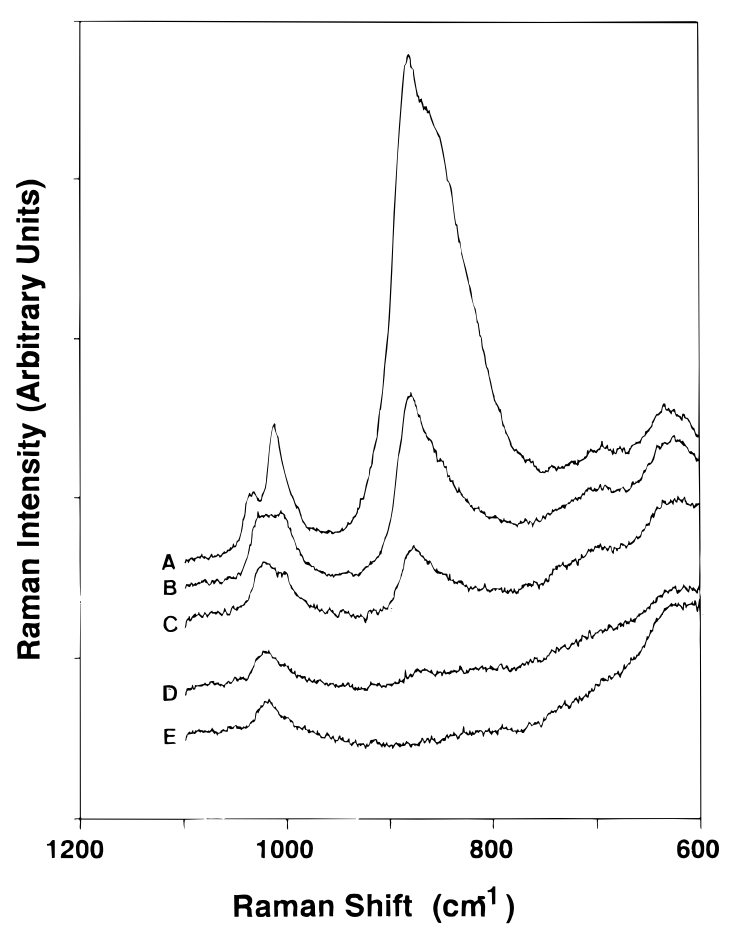

Figure 1. In situ Raman spectra of the $6 \% \mathrm{CrO}_{3} / \mathrm{ZrO}_{2}$ catalyst after calcination (A) and during butane dehydrogenation as a function of temperature $\left(\mathrm{B}, 250{ }^{\circ} \mathrm{C} ; \mathrm{C}, 300^{\circ} \mathrm{C} ; \mathrm{D}, 350{ }^{\circ} \mathrm{C}\right.$; and $\left.\mathrm{E}, 400{ }^{\circ} \mathrm{C}\right)$.

2. $\mathrm{CrO}_{3} / \mathrm{ZrO}_{2}$ Catalysts. The RS spectra of the $6 \mathrm{wt} \%$ $\mathrm{CrO}_{3} / \mathrm{ZrO}_{2}$ catalyst during butane dehydrogenation as a function of the reaction temperature are presented in Figure 1. The RS spectra of the 1 and $3 \mathrm{wt} \% \mathrm{CrO}_{3} / \mathrm{ZrO}_{2}$ catalysts are essentially identical, with the exception of the absolute band intensities, and are not shown. The RS spectrum after calcination is dominated by three strong bands at 1030, 1010, and $880 \mathrm{~cm}^{-1}$, which were previously assigned to a polychromate species. ${ }^{14}$ After calcination, the samples were cooled down and contacted with butane gas in the absence of oxygen at 250, 300, 350, and $400{ }^{\circ} \mathrm{C}$. The corresponding RS spectra are shown in Figure 1 and the absolute intensities of the three RS bands decrease with increasing reaction temperature. This decrease in intensity is due to the reduction of the Raman active $\mathrm{Cr}^{6+}$ to $\mathrm{Cr}^{3+}$ and $\mathrm{Cr}^{2+}$ species, which apparently give rise to weaker Raman signals.

The relative intensities of the 1030, 1010, and $880 \mathrm{~cm}^{-1}$ Raman as a function of reduction temperature are illustrated in Figure 2. The 880 and $1010 \mathrm{~cm}^{-1}$ Raman bands exhibit a parallel decrease in intensity, whereas the $1030 \mathrm{~cm}^{-1}$ Raman band intensity decreases independently and does not follow the same pattern. This was evidenced by plotting the different ratios of the band areas of the RS bands obtained by spectral deconvolution as a function of the reduction temperature. The ratio of the band areas of the Raman bands at 880 and $1010 \mathrm{~cm}^{-1}$ is around 20 independent of the reduction temperature. The band at $1030 \mathrm{~cm}^{-1}$ shifts to $1020 \mathrm{~cm}^{-1}$ and is still present during butane dehydrogenation at $400{ }^{\circ} \mathrm{C}$. This shift can be explained by the removal of the stronger $1010 \mathrm{~cm}^{-1}$ band during reduction. Thus, the three Raman band spectrum of Figure 1 is not due to only one surface chromium oxide species, but it is a combination of two distinct surface chromium oxide species: one species is characterized by a Raman band at $1030 \mathrm{~cm}^{-1}$ while the second species has Raman bands at 880 and $1010 \mathrm{~cm}^{-1}$.

On the basis of RS spectra of reference chromium oxide compounds, ${ }^{15}$ the first surface chromium oxide species is assigned to an isolated monochromate species and the second 


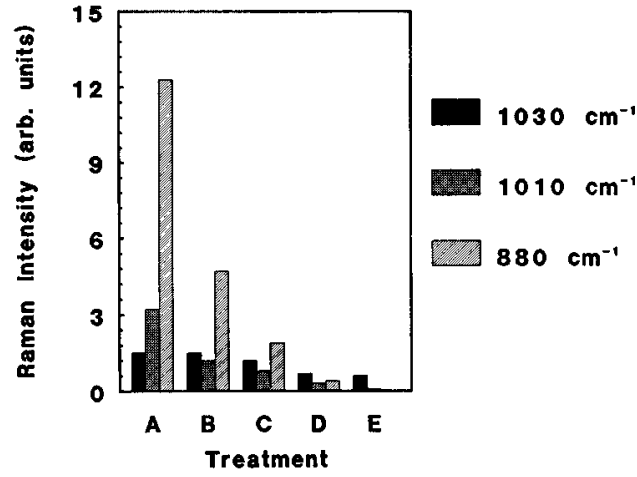

Figure 2. Percent reduction (decrease in the $\mathrm{Raman} \mathrm{Cr}=\mathrm{O}$ bond intensity) of the 1030,1010 , and $880 \mathrm{~cm}^{-1} \mathrm{RS}$ bands during butane dehydrogenation over the $6 \mathrm{wt} \% \mathrm{CrO}_{3} / \mathrm{ZrO}_{2}$ catalyst as a function of temperature: (A) after calcination and during butane dehydrogenation at $250{ }^{\circ} \mathrm{C}(\mathrm{B}), 300{ }^{\circ} \mathrm{C}(\mathrm{C}), 350{ }^{\circ} \mathrm{C}(\mathrm{D})$, and $400{ }^{\circ} \mathrm{C}(\mathrm{E})$.

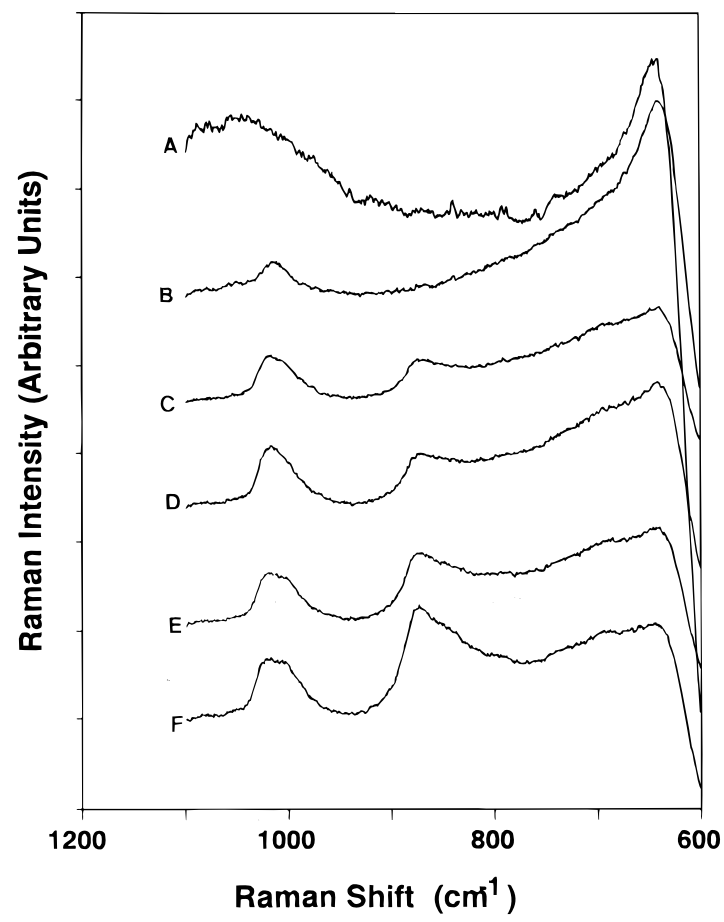

Figure 3. In situ Raman spectra of the $6 \% \mathrm{CrO}_{3} / \mathrm{ZrO}_{2}$ catalyst during methanol oxidation as a function of the $\mathrm{He}: \mathrm{O}_{2}$ ratio: 130:0 (A); 130:5 (B); 130:0 (C); 90:90 (D); 50:130 (E), and 0:130 (F).

surface chromium oxide species is assigned to a polychromate species. Thus, the isolated surface chromate species gives rise to $\mathrm{Cr}=\mathrm{O}$ vibrations at $1030 \mathrm{~cm}^{-1}$, and the polymerized surface chromate species gives rise to $\mathrm{Cr}=\mathrm{O}$ and $\mathrm{Cr}-\mathrm{O}-\mathrm{Cr}$ vibrations at 1010 and $880 \mathrm{~cm}^{-1}$, respectively. The two Raman bands at 880 and $1010 \mathrm{~cm}^{-1}$ can be regenerated by contacting the $\mathrm{CrO}_{3} / \mathrm{ZrO}_{2}$ catalysts with a mixture of butane and oxygen at 300 and $400{ }^{\circ} \mathrm{C}$, which shows that the reduction process is reversible.

The RS spectra of 6 wt $\% \mathrm{CrO}_{3} / \mathrm{ZrO}_{2}$ catalysts, obtained during methanol oxidation at $350{ }^{\circ} \mathrm{C}$, as a function of the gas composition is presented in Figure 3. In the presence of methanol and helium, no RS bands are observed due to reduction of the surface $\mathrm{Cr}$ oxide species and the RS spectrum is noisy due to some fluorescence. By introducing increasing amounts of oxygen in the mixture of methanol and helium, the RS bands at 1030,1010 , and $880 \mathrm{~cm}^{-1}$ become visible. The absolute intensities of all these bands increase with increasing amounts of oxygen, although the $1030 \mathrm{~cm}^{-1}$ band always remains relatively intense. The relative intensities of the 1030, 1010,

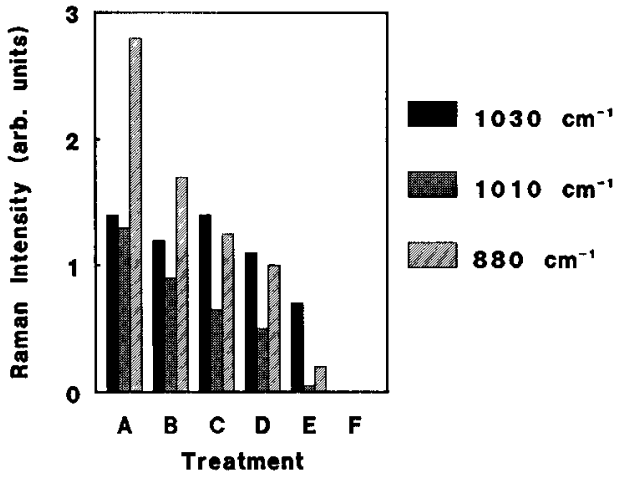

Figure 4. Percent reduction (decrease in the Raman $\mathrm{Cr}=\mathrm{O}$ bond intensity) of the 1030,1010 , and $880 \mathrm{~cm}^{-1} \mathrm{RS}$ bands during methanol oxidation over the $6 \mathrm{wt} \% \mathrm{CrO}_{3} / \mathrm{ZrO}_{2}$ catalyst as as a function of the $\mathrm{He}: \mathrm{O}_{2}$ ratio in the gas mixture: 130:0 (A), 130:5 (B), 130:0 (C), 90:90 (D), 50:130 (E), and 0:130 (F).

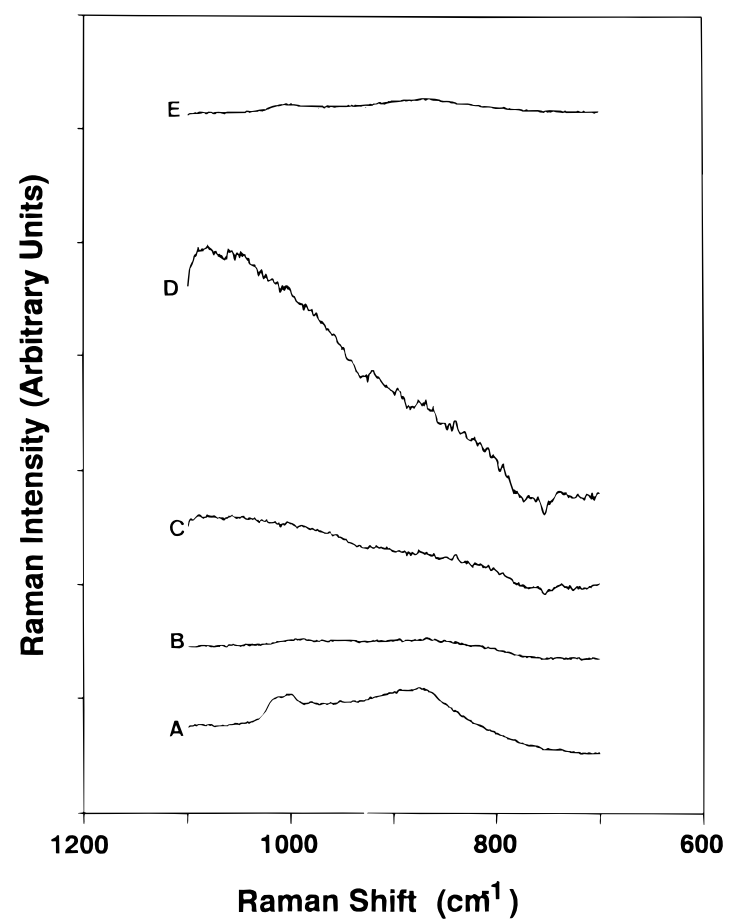

Figure 5. In situ Raman spectra of the $5 \% \mathrm{CrO}_{3} / \mathrm{Al}_{2} \mathrm{O}_{3}$ catalyst after calcination (A), during butane dehydrogenation as a function of temperature $\left(\mathrm{B}, 250{ }^{\circ} \mathrm{C} ; \mathrm{C}, 300{ }^{\circ} \mathrm{C}\right.$; and $\left.\mathrm{D}, 350^{\circ} \mathrm{C}\right)$ and during butane oxidation at $400{ }^{\circ} \mathrm{C}(\mathrm{E})$.

and $880 \mathrm{~cm}^{-1}$ bands as a function of the gas composition are illustrated in Figure 4. The ratio of the band intensities of the 880 and $1010 \mathrm{~cm}^{-1}$ bands is close to 2 , independent of the treatment. In addition, all the Raman bands decrease with decreasing amount of oxygen in the gas mixture, although the intensity of the band around $1030 \mathrm{~cm}^{-1}$ is the least affected during methanol oxidation.

3. $\mathrm{Cr} / \mathrm{Al}_{2} \mathrm{O}_{3}$ Catalysts. The $\mathrm{RS}$ spectra of the $5 \mathrm{wt} \% \mathrm{CrO}_{3} /$ $\mathrm{Al}_{2} \mathrm{O}_{3}$ catalyst during butane dehydrogenation/oxidation are shown in Figure 5. After calcination, the RS spectrum is characterized by bands at $1005-1000 \mathrm{~cm}^{-1}$ and at $880 \mathrm{~cm}^{-1}$, which start to disappear by flowing butane at $200{ }^{\circ} \mathrm{C}$ over the catalyst. Thus, a three-band spectrum is formed, similarly to that obtained for $\mathrm{CrO}_{3} / \mathrm{ZrO}_{2}$ catalysts, although the highfrequency component is weaker. Increasing of the reduction temperature gives rise to fluorescence (reflected by the noisy signal and nonflat baseline), which is suppressed by adding some oxygen to the gas mixture at $400{ }^{\circ} \mathrm{C}$ (Figure 5E). Thus, the surface chromium(VI) oxide species are essentially reduced 


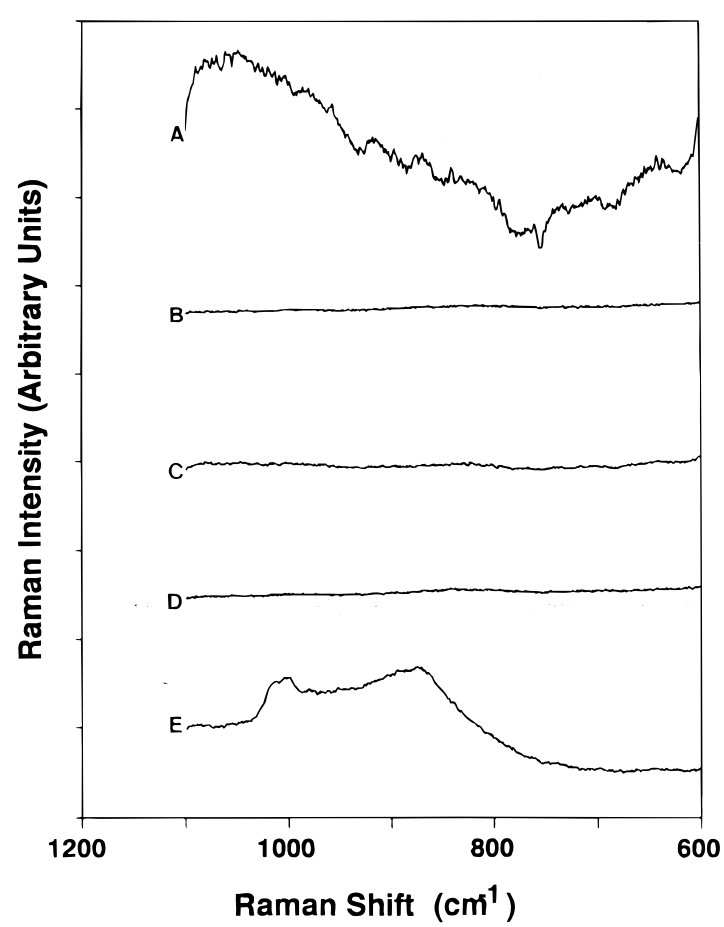

Figure 6. In situ Raman spectra of the $5 \% \mathrm{CrO}_{3} / \mathrm{Al}_{2} \mathrm{O}_{3}$ catalyst during methanol oxidation as a function of the $\mathrm{He}: \mathrm{O}_{2}$ ratio: 130:0 (A), 130:5 (B), 130:0 (C), 50:130 (D), and 0:130 (E).

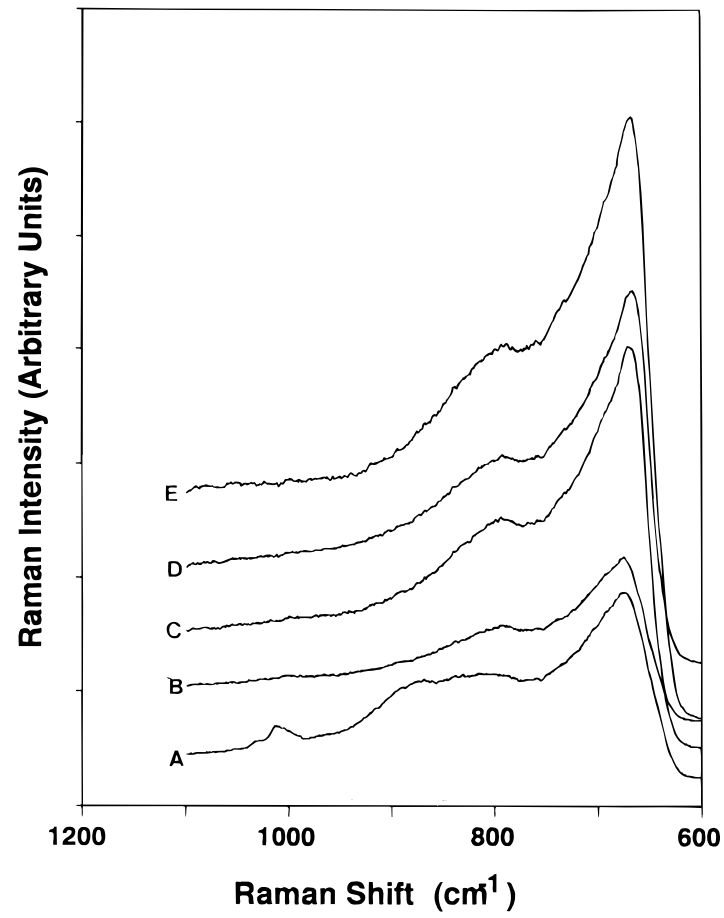

Figure 7. In situ Raman spectra of the $3 \% \mathrm{CrO}_{3} / \mathrm{TiO}_{2}$ catalyst after calcination (A) and during butane dehydrogenation as a function of temperature $\left(\mathrm{B}, 250{ }^{\circ} \mathrm{C} ; \mathrm{C}, 300{ }^{\circ} \mathrm{C} ; \mathrm{D}, 350{ }^{\circ} \mathrm{C}\right.$; and $\left.\mathrm{E}, 400{ }^{\circ} \mathrm{C}\right)$.

at elevated temperatures in the butane $/ \mathrm{O}_{2}$ environments. The RS spectra obtained during methanol oxidation as a function of the gas composition are presented in Figure 6. All Raman bands dissappear after introduction of methanol and a fluorescence background is induced in the absence of oxygen. The $\mathrm{CH}_{3} \mathrm{OH} / \mathrm{O}_{2}$ environments give rise to fluorescence-free spectra and reveal that the surface chromium oxide species are reduced under all reaction conditions. Thus, the surface chromium oxide species on alumina are more reducible than the surface chromium oxide species on zirconia (for polychromates).

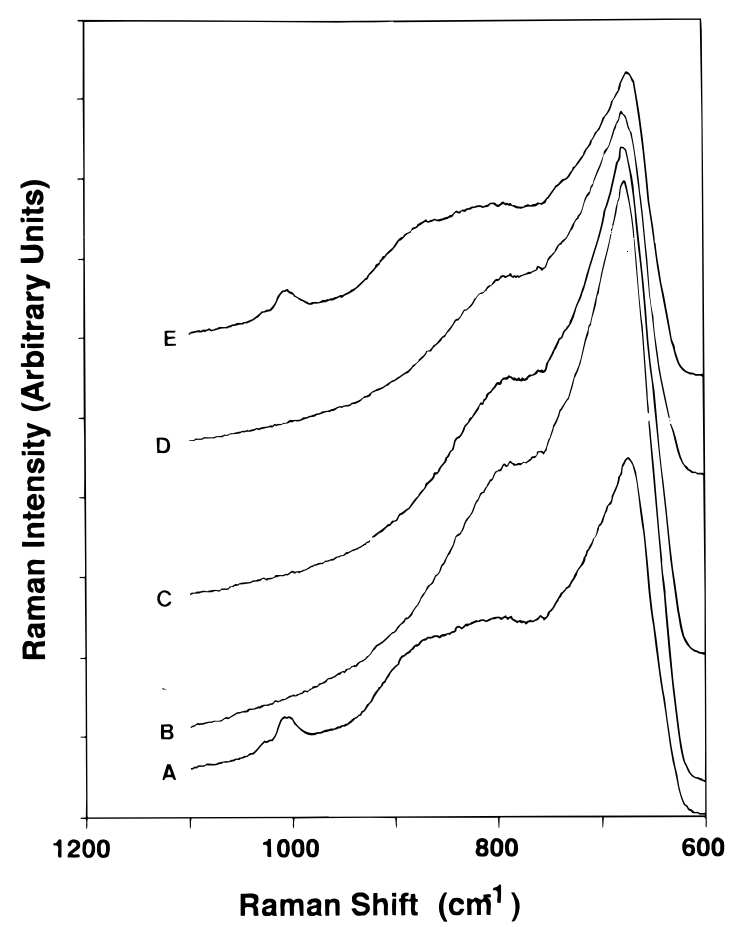

Figure 8. In situ Raman spectra of the $3 \% \mathrm{CrO}_{3} / \mathrm{TiO}_{2}$ catalyst after calcination (A) and during methanol oxidation as a function of the He: $\mathrm{O}_{2}$ ratio: 130:0 (B), 130:5 (C), 50:130 (D), and 0:130 (E).

4. $\mathrm{Cr} / \mathrm{TiO}_{2}$ Catalysts. The RS spectra of the supported $\mathrm{Cr} /$ $\mathrm{TiO}_{2}$ catalysts during butane dehydrogenation as a function of reaction temperature are presented in Figure 7. The Raman band at around $800 \mathrm{~cm}^{-1}$ originates from the anatase phase of the $\mathrm{TiO}_{2}$ support ${ }^{13,15,16}$ and is not related to the surface chromium oxide species. After calcination, RS bands at 1030, 1010, and $880 \mathrm{~cm}^{-1}$ are observed and a three-band spectrum is obtained, which is similar to that of supported $\mathrm{Cr} / \mathrm{ZrO}_{2}$ catalysts. The three-band spectrum totally disappears on introducing butane at $200{ }^{\circ} \mathrm{C}$ and it can only be partially regenerated by introducing some oxygen in the butane stream. The RS spectra of supported $\mathrm{Cr} / \mathrm{TiO}_{2}$ catalysts during methanol oxidation are shown in Figure 8 , and the same general trends are observed as for butane dehydrogenation.

5. $\mathrm{Cr} / \mathrm{SiO}_{2} / \mathrm{TiO}_{2}$ Catalysts. The $\mathrm{RS}$ spectra of the 1 wt $\%$ $\mathrm{CrO}_{3} / 3 \% \mathrm{SiO}_{2} / \mathrm{TiO}_{2}$ catalyst during butane dehydrogenation as a function of the reaction temperature are presented in Figure 9. The RS spectra of the 1 wt $\% \mathrm{CrO}_{3} / 3 \% \mathrm{TiO}_{2} / \mathrm{SiO}_{2}$ and $\mathrm{CrO}_{3} /$ $\left(\mathrm{SiO}_{2}+\mathrm{TiO}_{2}\right)$ catalysts behave similarly to $\mathrm{CrO}_{3} / \mathrm{SiO}_{2}$ and $\mathrm{CrO}_{3} / \mathrm{TiO}_{2}$, respectively, and will not be discussed. The fluorescence background of these catalysts during catalytic conditions is, however, stronger due to the presence of the silica component. After calcination of the $1 \mathrm{wt} \% \mathrm{CrO}_{3} / 3 \% \mathrm{SiO}_{2} /$ $\mathrm{TiO}_{2}$ catalyst, two bands at 1000 and $982 \mathrm{~cm}^{-1}$ are observed, which were previously assigned as monochromate species. ${ }^{16}$ Both bands start to decrease in intensity after introduction of butane at $200{ }^{\circ} \mathrm{C}$ and totally disappear after butane dehydrogenation at $300{ }^{\circ} \mathrm{C}$. The same results were obtained during methanol oxidation.

6. $\mathrm{Cr} / \mathrm{Nb}_{2} \mathrm{O}_{5}$ Catalysts. The dehydrated niobia-supported chromium oxide catalysts possess Raman bands at around 890 and $970 \mathrm{~cm}^{-1}$, which were previously assigned to a dehydrated chromium oxide species. ${ }^{27}$ However, no new spectroscopic features are observed during methanol oxidation and butane dehydrogenation/oxidation and the RS spectra are not presented for brevity. The previously assigned RS bands must thus be regarded as tentative and are possibly due to bulk $\mathrm{Nb}_{2} \mathrm{O}_{5}$, which gives rise to strong RS spectra. 


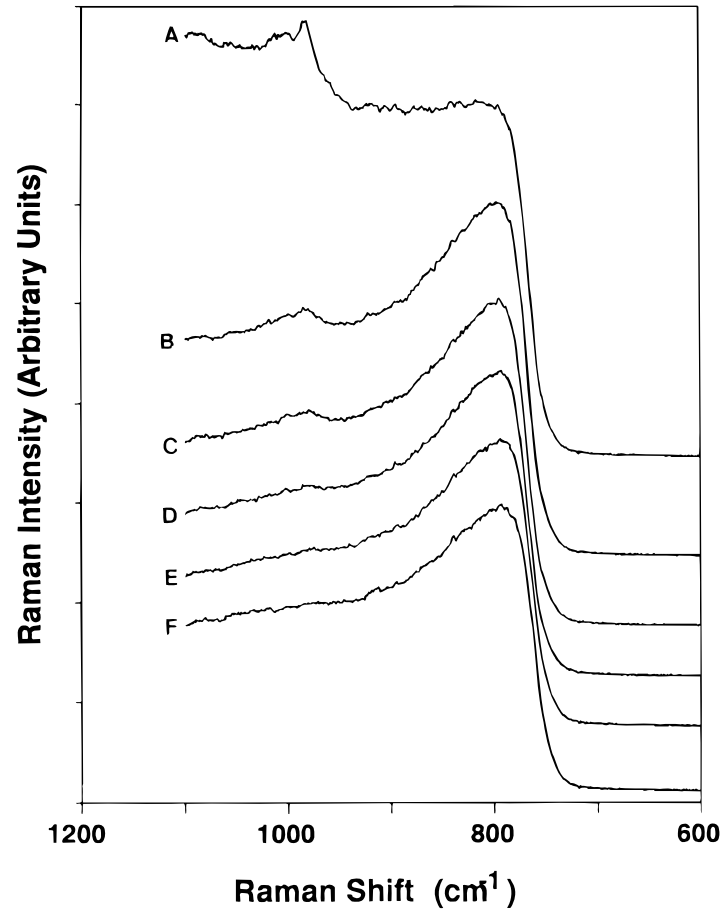

Figure 9. In situ Raman spectra of the $1 \% \mathrm{CrO}_{3} / \mathrm{SiO}_{2} / \mathrm{TiO}_{2}$ catalyst after calcination (A) and during butane dehydrogenation as a function of temperature $\left(\mathrm{B}, 200{ }^{\circ} \mathrm{C} ; \mathrm{C}, 250{ }^{\circ} \mathrm{C} ; \mathrm{D}, 300{ }^{\circ} \mathrm{C} ; \mathrm{E}, 350{ }^{\circ} \mathrm{C}\right.$; and $\mathrm{F}$, $\left.400{ }^{\circ} \mathrm{C}\right)$.

\section{Discussion}

Spectroscopic techniques, like Raman spectroscopy, have to be developed which allow measurements under conditions as close as possible to "real" catalytic conditions. Thus, in general, in situ spectroscopic studies are required to fully understand the catalytic action of supported metal oxide catalysts. In this work, the extent of reduction of supported chromium oxide catalysts in methanol oxidation and butane dehydrogenation/ oxidation has been probed using in situ Raman spectroscopy. The extent of reduction of surface chromium oxides during catalysis is strongly dependent on the support type and merits a more detailed discussion, which will cover the following topics: (1) the potential of in situ Raman spectroscopy to probe surface chromium oxide species during catalysis and (2) the redox behavior of supported chromium oxides.

1. Evaluation of in Situ Raman Spectroscopy. Raman spectroscopy is an optical technique and, therefore, is applicable for studying the structural changes of the surface chromium oxide species under in situ conditions where the temperature and gas composition of the catalyst can be controlled. In the present characterization study, the reaction temperature was varied between 200 and $500{ }^{\circ} \mathrm{C}$ and various gas composition were examined. Although Raman spectroscopy is a bulk technique, it provides detailed information about the surface chromium oxide species during catalytic reactions since the supported chromium oxides are all located on the surface of the inorganic oxides (100\% dispersed). The same band patterns were obtained under catalytic reaction conditions as under dehydrated conditions and only small shifts to lower energy values were observed. These small Raman band shifts are due to the relatively high temperatures $(\mathrm{Cr}=\mathrm{O}$ vibrations change slightly with temperature) and to some hydrogen bonding of the probe molecules during catalysis.

The biggest advantage of RS is that it is able to distinguish between different polymerization degrees of $\mathrm{Cr}^{6+}$. The molecular vibrations of surface $\mathrm{Cr}^{6+}$ are always easy to measure because of the large change in polarizability of the $\mathrm{Cr}=\mathrm{O}$ and $\mathrm{Cr}-\mathrm{O}-\mathrm{Cr}$ bands during vibration. This results in relatively strong Raman bands, but this is not the case for the lower oxidation states of $\mathrm{Cr}$ (i.e., $\mathrm{Cr}^{3+}$ and $\mathrm{Cr}^{2+}$ ). Thus, the decrease of intensity of the $\mathrm{Cr}^{6+}$ Raman bands during butane dehydrogenation and methanol oxidation is not compensated by an increase in intensity of the RS bands of reduced $\mathrm{Cr}$ species. Consequently, information about redox behavior can only be obtained by following the relative intensities of the $\mathrm{Cr}^{6+} \mathrm{RS}$ bands as a function of reaction temperature. However, such reduction studies enable us to clearly distinguish for the first time two surfaces $\mathrm{Cr}^{6+}$ species differing in redox behavior, i.e. a difficult to reduce monochromate species characterized by a RS band around $1030 \mathrm{~cm}^{-1}$ and a more easily reducible polychromate species with RS bands at 1010 and $880 \mathrm{~cm}^{-1}$. The copresence of chromate and polychromate surface species was already proposed by one of us from diffuse reflectance spectroscopy, ${ }^{28,29}$ and the present results complete the picture of surface chemistry and spectroscopy of chromium oxides.

One possible limitation of Raman spectroscopy for the characterization of supported chromium oxide catalysts occurs when the vibrations of the oxide support overlap with the vibrations arising of the surface chromium oxide phase. However, most oxide supports give only weak Raman signals (i.e. weak backgrounds) and in this work some minor problems were encountered with niobia and to a lesser extent with titania. The weak support Raman signals make this characterization preferable for supported metal oxide catalysts than infrared spectroscopy, which gives rise to strong support IR signals. Raman spectroscopy can suffer from fluorescence during catalytic action. This is especially true for silica- and aluminabased catalysts and at high reaction temperatures. Such fluorescence complicates the quantitative interpretation of the obtained RS spectra, especially in the absence of oxygen in the gas phase.

2. Redox Behavior of Supported Chromium Oxides. The redox behavior of supported chromium oxides is strongly dependent on the specific support and can be evaluated by following the relative intensities of the $\mathrm{Cr}^{6+} \mathrm{RS}$ bands as a function of the reaction temperature during butane dehydrogenation. The following sequence in redox behavior can be deduced from the reported Raman spectra: $3 \% \mathrm{TiO}_{2} / \mathrm{SiO}_{2} \approx$ $3 \% \mathrm{SiO}_{2} / \mathrm{TiO}_{2} \approx\left(\mathrm{SiO}_{2}+\mathrm{TiO}_{2}\right) \approx \mathrm{TiO}_{2}>\mathrm{ZrO}_{2}$. The $\mathrm{SiO}_{2}$ and $\mathrm{Al}_{2} \mathrm{O}_{3}$ supports cannot be evaluated because of the fluorescence background. The differences in redox behavior of surface chromium oxides between different supports have been previously observed by diffuse reflectance spectroscopy and were explained in terms of hardness-softness concepts, first introduced by Pearson. ${ }^{30}$ The present investigation, however, gives an important extension to other support types and preparation methods. The obtained sequence also reveals that the order of magnitude variation in turnover frequencies (TOF, the number of methanol molecules converted to redox products per surface chromium species per second) previously observed for methanol oxidation does not correlate with the reducibility of the supported chromium oxide catalysts. ${ }^{12,13}$ Although an inorganic support acts as an important ligand influencing the stability of supported chromium oxide species, the catalytic action of supported chromium oxide catalysts in redox reactions is determined by its reduction and reoxidation properties. Thus, supported metal oxides need to behave as a reversible redox couple to be active in gas phase catalysis.

\section{Conclusions}

In situ Raman spectroscopy is a valuable tool for the characterization of supported chromium oxide catalysts under 
catalytic conditions. Reactivity studies with methanol and butane show that supported chromium oxides are easily reduced and their redox behavior mainly depends on the specific support ligand. We have demonstrated for the first time by Raman spectroscopy that two types of surface chromium oxide species are present on inorganic oxides: a monomeric species, which is difficult to reduce, and a polymeric species, which is more easily reducible on the same support. Both species are present on $\mathrm{ZrO}_{2}, \mathrm{TiO}_{2}, 3 \% \mathrm{SiO}_{2} / \mathrm{TiO}_{2},\left(\mathrm{SiO}_{2}+\mathrm{TiO}_{2}\right)$, and $\mathrm{Al}_{2} \mathrm{O}_{3}$, whereas $\mathrm{SiO}_{2}$ and $3 \% \mathrm{TiO}_{2} / \mathrm{SiO}_{2}$ supports possess only monochromate on their surfaces. The sequence in redox behavior of supported chromium oxide species is not directly related with the catalytic activity during methanol oxidation. In situ diffuse reflectance spectroscopy with a specially designed Praying mantis cell to quantify the extent of $\mathrm{Cr}^{6+}$ reduction and the formation of $\mathrm{Cr}^{3+}$ and $\mathrm{Cr}^{2+}$ species under catalytic conditions is under way. Such studies, in combination with on line catalytic measurements, are necessary for the development of general structure-activity relationships in heterogeneous catalysis.

Acknowledgment. B.M.W. acknowledges the National Fund of Scientific Research (N.F.W.O) of Belgium for a grant as research assistant and for a travel grant to visit the Zettlemoyer Center for Surface Studies of Lehigh University. The work at Lehigh University was supported by the Division of Basic Energy Sciences, Department of Energy (Grant DEFG93ER14350).

\section{References and Notes}

(1) Hogan, J. P. Appl. Indust. Catal. 1983, 1, 149.

(2) Hogan, J. P.; Banks, R. L. Belg. Patent 530617, 1953; U.S. Patent $2,825,721,1958$

(3) Hogan, J. P. J. Polym. Sci. 1970, 8, 2637.

(4) Hogan, J. P.; Norwood, D. D.; Ayres, C. A. J. Appl. Polym. Sci. $1981,36,49$.
(5) McDaniel, M. P. Adv. Catal. 1985, 33, 47.

(6) Poole, C. P.; MacIver, D. S. Adv. Catal. 1967, 17, 223.

(7) Frey, F. E.; Huppke, W. F. Ind. Eng. Chem. 1933, 25, 54.

(8) Frey, F. E.; Huppke, W. F. U.S. Patent 2,098,959, 1937.

(9) McDaniel, M. P. Ind. Eng. Chem. Res. 1988, 27, 1559.

(10) Weckhuysen, B. M.; Wachs, I. E.; Schoonheydt, R. A. Chem. Rev., submitted for publication.

(11) Hardcastle, F. D.; Wachs, I. E. J. Mol. Catal. 1988, 46, 173. 209.

(12) Kim, D. S.; Tatibouet, J. M.; Wachs, I. E. J. Catal. 1992, 136,

(13) Kim, D. S.; Wachs, I. E. J. Catal. 1993, 142, 166.

(14) Vuurman, M. A.; Wachs, I. E. J. Phys. Chem. 1992, 96, 5008.

(15) Vuurman, M. A.; Wachs, I. E.; Stufkens, D. J.; Oskam, A. J. Mol. Catal. 1993, 80, 209.

(16) Jehng, J. M.; Wachs, I. E.; Weckhuysen, B. M.; Schoonheydt, R. A. J. Chem. Soc., Faraday Trans. 1995, 91, 953.

(17) Weckhuysen, B. M.; Schoonheydt, R. A.; Jehng, J. M.; Wachs, I. E.; Cho, S. J.; Ryoo, R.; Kijlstra, S.; Poels, E. J. Chem. Soc., Faraday Trans. 1995, 91, 3245.

(18) Vuurman, M. A.; Stufkens, D. J.; Oskam, A.; Moulijn, J. A. J. Mol. Catal. 1990, 60, 83.

(19) Vuurman, M. A.; Hardcastle, F. D.; Wachs, I. E. J. Mol. Catal. 1993, 84, 193.

(20) Deo, G.; Wachs, I. E. J. Phys. Chem. 1991, 95, 5889.

(21) Ianibello, A.; Marengo, S.; Tittarelli, P.; Morelli, G.; Zecchina, A. J. Chem. Soc., Faraday Trans. 1 1984, 80, 2209.

(22) Turek, A. M.; Wachs, I. E.; DeCanio, E. J. Phys. Chem. 1992, 96, 5000.

(23) Zecchina, A.; Garrone, E.; Ghiotti, G.; Morterra, C.; Borello, E. J. Phys. Chem. 1975, 79, 966.

(24) Nishimura, M.; Thomas, J. M. Catal. Lett. 1993, 19, 33.

(25) Wachs, I. E. Catal. Today 1996, 27, 437.

(26) Burns, R. G. Mineral applications of crystal field theory. Crystal field theory, 2nd ed.; Cambridge University Press: London, 1993.

(27) Jehng, J. M.; Wachs, I. E. Appl. Catal. A 1992, 83, 179.

(28) Weckhuysen, B. M.; De Ridder, L. M.; Schoonheydt, R. A. J. Phys. Chem. 1993, 97, 4756.

(29) Weckhuysen, B. M.; Verberckmoes, A. A.; Buttiens, A. L.; Schoonheydt, R. A. J. Phys. Chem. 1994, 98, 579.

(30) Pearson, R. G. J. Am. Chem. Soc. 1963, 85, 3533.

JP9605430 